\title{
14
}

\section{Depression in Alzheimer's Disease: The Roles of Cholinergic and Serotonergic Systems}

\author{
Enver Ahmet Demir • Okan Tutuk • Hatice Dogan • Cemil Tumer \\ Department of Physiology, Faculty of Medicine, Hatay Mustafa Kemal University, \\ Hatay, Turkey
}

Author for correspondence: Enver Ahmet Demir, Department of Physiology, Faculty of Medicine, Hatay Mustafa Kemal University, Hatay, Turkey. Email:demirea@live.com Doi: http://dx.doi.org/10.15586/alzheimersdisease.2019.ch14

\begin{abstract}
Although depression and Alzheimer's disease fundamentally result from distinct pathophysiological events, their coincidence is far from a rare occurrence. In addition to the difficulty in the diagnosis of depression in the patients with a cognitive impairment, care givers and even physicians are mostly unaware that depression and Alzheimer's disease can coexist. While depression has already a devastating impact on quality of life by itself, coinciding depression and Alzheimer's disease may advance to a cataclysmic magnitude. This chapter underlines obstacles in the recognition of depression in the Alzheimer's patients following a brief introduction to the concept of depression. Depression and Alzheimer's disease appear to intersect in the cholinergic and serotonergic systems which may engender an exquisite strategy in the treatment of both disorders. Therefore, potential cholinergic and serotonergic targets are also emphasized.
\end{abstract}

Keywords: Alzheimer's disease; cholinergic system; coincidence; depression; serotonergic system

In: Alzheimer's Disease. Thomas Wisniewski (Editor), Codon Publications, Brisbane, Australia. ISBN: 978-0-646-80968-7; Doi: http://dx.doi.org/10.15586/alzheimersdisease.2019

Copyright: The Authors.

License: This open access article is licensed under Creative Commons Attribution 4.0 International (CC BY 4.0). https://creativecommons.org/licenses/by-nc/4.0/ 


\section{INTRODUCTION}

Depression is an affective disorder as old as mankind. Hippocrates has defined depressive psychological state as "melancholia," which means "black bile" in Greek, by the words of "despair, apathy, unwillingness, insomnia, anxiety, incompetence, gloominess, sadness and fear" in around 400 BC (1). The brief description of depression is being possessed by unhappiness, moodiness and unwillingness (2). However, its description as a medical condition is continually evolving with the efforts of classification to make differential diagnosis clearer. Depression is an additional mental burden in Alzheimer's patients who already struggle with cognitive impairments. Both depression and Alzheimer's disease lower quality of life and harden daily activities of the patients who are mostly elders. Alzheimer's disease often does not have a good prognosis whereas depression is a reversible, but recurrent disorder. Almost one-third of the Alzheimer's patients suffer depression $(3,4)$. This chapter focuses on the interrelation between depression and Alzheimer's disease, and discusses common properties of these neuropsychiatric disorders.

\section{HOW DO WE RECOGNIZE DEPRESSION?}

Diagnostic and Statistical Manual of Mental Disorders (DSM) by the American Psychiatric Association is the main guideline to diagnose depressive disorders whereas International Classification of Diseases (ICD) by the World Health Organization is the global system for reporting health conditions. According to the fifth edition of DSM, depressive disorders are categorized as major depressive disorder, dysthymic disorder, disruptive mood disorder, premenstrual dysphoric disorder, substance or drug related depressive disorder, depressive disorder due to a medical condition, and otherwise undifferentiated depressive disorder (5). With the system of ICD, the most commonly diagnosed depressive disorders are single depressive episode, recurrent depressive disorders, and persistent mood disorders (6). Depression is the most prevalent psychiatric disorder among general population (7). The patients with depression often have low self-esteem, suffer overwhelming unwillingness, and are afflicted by attention and concentration deficits which result in cognitive impairments $(6,8)$. Depression may exceed being an affective problem and lead to physical abnormalities. It can coincide with and aggravate existing physical pathologies $(2,6,8)$. On the other side, chronic diseases can also generate depressive disorders $(2,9,10)$. Together with its complications including the aggravation of physical health conditions, depression is a serious public health concern which also creates an important economic burden (10-12). Concerningly, depression has become the leading cause of disability (13). This insidious pandemic urges a better understanding of its pathophysiological mechanism and so, development of more advanced treatment options. 


\section{COGNITIVE DYSFUNCTION MAY LOOK ALIKE DEPRESSION}

Although depression occurs frequently, it should not be mistaken as its diagnosis is unchallenging, particularly for the patients with cognitive impairment. Depressive symptoms are summarized above; however, the cognitive impairment can easily be confused with depression and vice versa. Lowered self-esteem, self-blame, forgetfulness and indecisiveness are shared behavioral symptoms of depression and cognitive impairment. Furthermore, hypomimia, apathy, psychomotor slowness, fatigue, and reluctance to communicate are the signs a physician may notice in a depressive patient which again resemble cognitive dysfunction $(14,15)$. Therefore, in the patients with cognitive impairment, diagnosis of depression often requires scrutinization of medical history and discrimination of the affective disorder with overlapping signs of cognitive inability. Depression can emerge at any age, but its prevalence is higher in adults, especially between 55 to 74 years old (16). Also, women are reported to experience depression about two times more than men $(11,16)$, indicating that sex is a risk factor for depression (17). Besides, there are numerous other factors that create a tendency toward depression such as divorce, separation, loneliness, and low socioeconomic status. (18).

\section{THE COINCIDENCE OF DEPRESSION AND ALZHEIMER'S DISEASE}

Epidemiological and longitudinal studies indicate that there is a relation between Alzheimer's and depression. However, it is debatable whether depression is a symptom arisen from the neurodegeneration or a reaction against cognitive inabilities. Some authors are defending that depression is a preceding pathology and a risk factor for Alzheimer's disease whereas some others suggest that depression co-occurs in Alzheimer's disease, and it becomes apparent as a component of Alzheimer's $(4,19)$.

A yearly increase in elderly population is predicted in almost all countries (20). Because age is an individual risk factor for Alzheimer's disease (3), an aging population means more patients with Alzheimer's disease. About $5 \%$ of the people over 65 years have dementia and an additional $5 \%$ increases every 5 years. Thus, the prevalence of dementia is as high as $40 \%$ after 95 years of age (21). Today, it is estimated that there are 35 million demented people all around the world and this number is projected to be 115 million in 2050 (22).

Alzheimer's disease is the most common form of dementia (23). One-ninth people over 65 years of age and one-third over 85 years struggle with Alzheimer's disease (3). Alzheimer's disease affects more than 5 million people only in the United States and it is reported to be the fourth cause of death (24). Furthermore, coinciding pathologies can significantly increase the incidence of the disease. For example, the risk for Alzheimer's disease is 3 to 5 times more in Down's syndrome (25). 
Depression is an affective disorder that can afflict who takes a medical treatment and also, it is more prevalent in inpatients and elders under nursing care (3). Depression is a notable problem for overall elderly health. It has higher recurrence rates in elders than middle-aged people (26). Depression soars the death ratio independently of any medical interventions in patients under the nursing care (27). Suicide is the gravest consequence of depression and depressive elders have the highest suicide rates in all ages (28). Startlingly, suicidal ideation has been reported in $45 \%$ of the patients with concurring depression and Alzheimer's disease (29).

Depression is considered to be a "syndrome" rather than a "disease" which presently lacks a definitive biomarker and hence, is diagnosed by subjective questionnaire inventories. These inventories mainly aim to inspect neuropsychiatric symptoms such as negative emotional state, changes in personality and psychotic signs. The emotional and psychotic symptoms are relatively common in the Alzheimer's patients (30). Dysphoria, anxiety, aggressiveness, psychomotor agitation, loss of interest, and sleep disorders are the most frequent depressive symptoms. These symptoms encumber the care of Alzheimer's patients which is already difficult without them (Figure 1).

Clinical studies suggest that depression coincides with Alzheimer's disease in more than a half of the patients (29). Besides, depression in Alzheimer's disease often resembles severe depression, but with a variety of ambiguous symptoms.

\section{DEPRESSION AND ALZHEIMER'S DISEASE SHARE NEUROPSYCHOLOGICAL SIGNS}

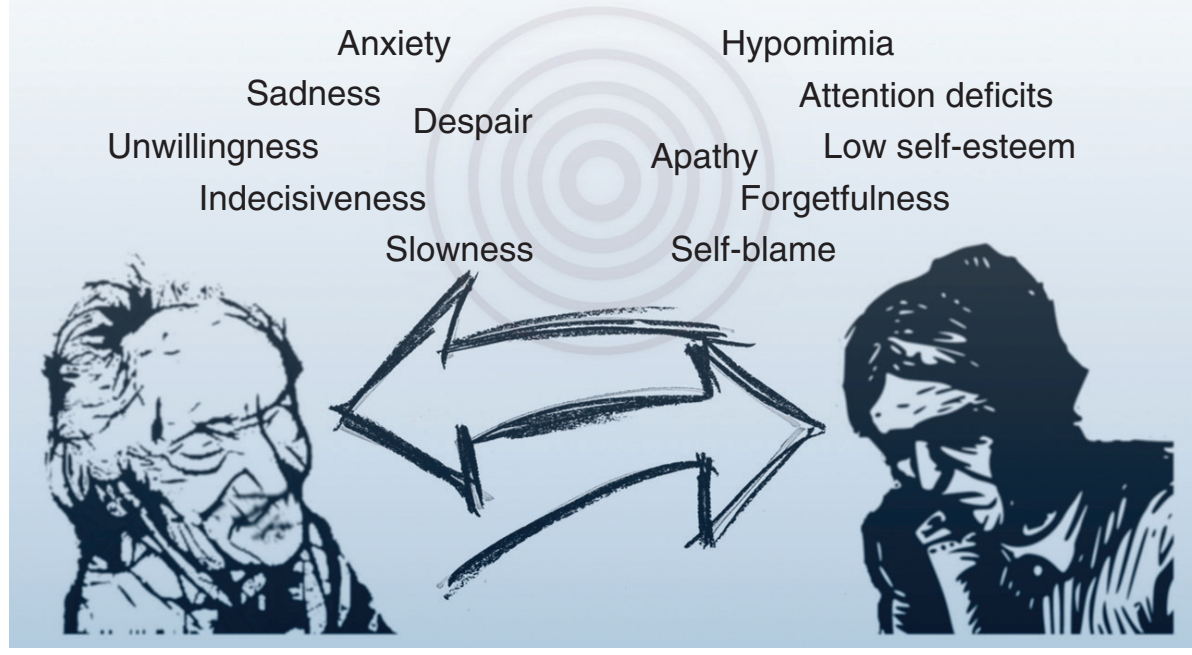

Figure 1 Depression and Alzheimer's disease are often manifested with similar neuropsychological symptoms and signs. 
For example, depression in Alzheimer's disease can be represented with social isolation, self-abnegation or aggressiveness $(3,4)$. However, apathy and loss of interest remains to be the most common symptoms in coinciding depression and Alzheimer's disease $(4,31)$.

Diagnosis of depression in Alzheimer's disease is a strenuous task due to the lack of an objective and repeatable laboratory test to identify depression. Because of similarities with the patients with Alzheimer's disease, depression inventories can be misguiding. Accordingly, it is important to emphasize that the incidence of depression gradually increases from mild to moderate cognitive impairment whereas decreases sharply in severe dementia (32). This decrease in incidence is a clear indicator of the obstacle in the diagnosis of coexisting depression in Alzheimer's disease.

\section{WHAT DOES LIE BEHIND COINCIDING ALZHEIMER'S DISEASE AND DEPRESSION?}

As mentioned above, the coincidence of Alzheimer's and depression is not a rare occurrence, and it creates a serious challenge to the diagnosis and quality of life. Although the two pathologies converge on behavioral and cognitive disturbances, they apparently do not originate in a common pathophysiological basis. However, they have a number of overlapping features that may explain the high comorbidity of Alzheimer's disease and depression.

The first report hinting the relation between Alzheimer's and depression dates back to late 1920s. Herz and Fünfgeld (33) have described depression as a preceding disorder that is immediately followed by deteriorations in memory in Alzheimer's patients. Numerous subsequent researches confirmed this link up to now, but post-mortem studies are peculiarly important since there is not a definitive ante-mortem diagnostic tool for Alzheimer's disease (34). Because longitudinal studies are invaluable means to reveal if there is a relation between seemingly distinct conditions, we will briefly discuss the prominent longitudinal studies in which post-mortem diagnosis was established.

In 2004, Milwain and Nagy (35) examined 89 histopathologically confirmed Alzheimer's patients with depression and found that the patients in the intermediate stage of the disease scored lower in CAMCOG, a neuropsychological battery to assess cognition (36), than the patients without depression. The worsened cognition in depressive Alzheimer's patients was implying a deterioration in the neuropathology, although this was not evidenced in that report. Rapp et al. (37) have investigated the post-mortem brains of 95 patients with clinically diagnosed Alzheimer's disease, of which 44 had a life-time history of major depressive disorder and 51 without depression. They noted that the Alzheimer's patients who suffered a life-time depression had about two times more amyloid plaques and neurofibrillary tangles in their hippocampi. In another longitudinal study that presents patient data from almost 40 years, Brunnström et al. (38) emphasized that the onset of dementia is lower in the depression sufferer Alzheimer's patients compared to those without depression. 
Alzheimer's disease and depression appear to have a reciprocal relationship. Depression is an individual risk factor for Alzheimer's disease (39) even when the latency between the two pathologies is as late as more than 25 years (40). Preceding depression is a specifically notable predictor of Alzheimer's disease for the patients who do not carry apolipoprotein E (ApoE) $\epsilon 4$ allele which is an Alzheimer'sassociated polymorphism (41). Thereby, non-ApoE4 allele carriers with depression have higher risk for Alzheimer's disease when compared with whom without depression. Furthermore, depression can have an outrageously high frequency in Alzheimer's disease. Usman et al. (42) have reported that depression was observed in three-fourths of the Alzheimer's patients without considering sex as a variable, and the prevalence was as high as $90 \%$ in females. This is particularly important because depression does not only aggravate amyloid pathology, but also worsens the clinical progress in Alzheimer's disease (43).

The mentioned interrelation points out some shared molecular features in Alzheimer's and depression even though they apparently originate from diverse pathological processes. Disturbances in the neurotransmitter systems and hypothalamic-pituitary-adrenal axis are prevailing peculiarities shared in the two pathologies. Indeed, the functions of the brain cannot be accredited to any individual neurotransmitter or neuromodulator because all systems should be operational in a stupendous harmony to achieve an efficient function. However, aberrations in the cholinergic, monoaminergic and serotonergic transmission are evident in both Alzheimer's disease and depression which compose a pathophysiological intersection.

Cholinergic system in the central nervous system consists of two sub-systems as nicotinic and muscarinic. Although cholinergic projections are clustered in distinct regions, both nicotinic and muscarinic receptors are widely distributed throughout the brain and hence, cholinergic transmission involves in numerous brain functions that are carried out by diverse brain areas (44). The nicotinic system works out through the neuronal nicotinic acetylcholine receptors which are simply cation channels (45) whereas the muscarinic system employs any of the five muscarinic acetylcholine receptors (M1-5) which all are G-protein coupled receptors (46). It is long known that cholinergic dysfunction is a problem in Alzheimer's disease (47). The cholinergic hypothesis of Alzheimer's disease proposes that the deterioration in the cholinergic signaling is responsible for learning and memory deficits, a condition which also can be experimentally mimicked by the administration of anti-cholinergic drugs (48). This hypothesis is supported by symptom relieving effects of acetylcholine esterase inhibitors whereas disapproved by the presence of cholinesterase inhibitor-resistant patients (48). Nevertheless, the cholinergic system is evidently disturbed in a remarkable portion of the patients and it shows a correlation with cognitive inabilities (49). This is probably because the cholinergic neurons are particularly affected by the amyloid accumulation (50). With regard to the cholinergic system, the relation between Alzheimer's and depression seems to be paradoxical, considering that reduced cholinergic signaling is linked to cognitive decline. The involvement of the cholinergic system in depression is known for almost 50 years (51) and preliminary studies have underlined the hyperactivity in the cholinergic signaling in depression (52). Consecutive researches have noted that enhanced cholinergic transmission leads to depression $(53,54)$ and 
antagonizing nicotinic signaling can exert an anti-depressant-like effect (55). Contrarily, the activation of a sub-type of nicotinic receptors, alpha7 receptor, has been shown to alleviate depression in mice through restoring the hippocampal function (56). Therefore, instead of a widespread contribution of the cholinergic system to depression, its influence on hippocampus should be taken into account. As illustrated in Figure 2, decreased cholinergic innervation diminishes the hippocampal neurogenesis and function, and improving the cholinergic transmission by means of cholinesterase inhibitors reverses this consequence (53). In regard to alterations in the cholinergic system, the hippocampus is the crossroad where cognitive deficits meet with depressive behaviors. This probably explains the finding of that cholinesterase inhibitors improve neuropsychiatric symptoms in some Alzheimer's patients $(57,58)$. On the other side, it should be kept in mind that cholinergic hyperactivity created by cholinesterase inhibitors can result in depression (59) and hence, fine dose adjustment and a strict follow-up are particularly important issues in the Alzheimer's patients with a history of depression.

The other neurotransmitter system that bridges between Alzheimer's disease and depression is the serotonergic system that is named after its neurotransmitter, serotonin (5-hydroxytryptamine; 5-HT). Serotonin has 7 families of receptors $\left(5-\mathrm{HT}_{1-7}\right)$ which are all G-protein coupled except for the ionotropic $5-\mathrm{HT}_{3}$

\section{CHOLINERGIC ALTERATIONS HAPPEN IN DEPRESSION AND ALZHEIMER'S DISEASE}

\section{Alzheimer's disease}

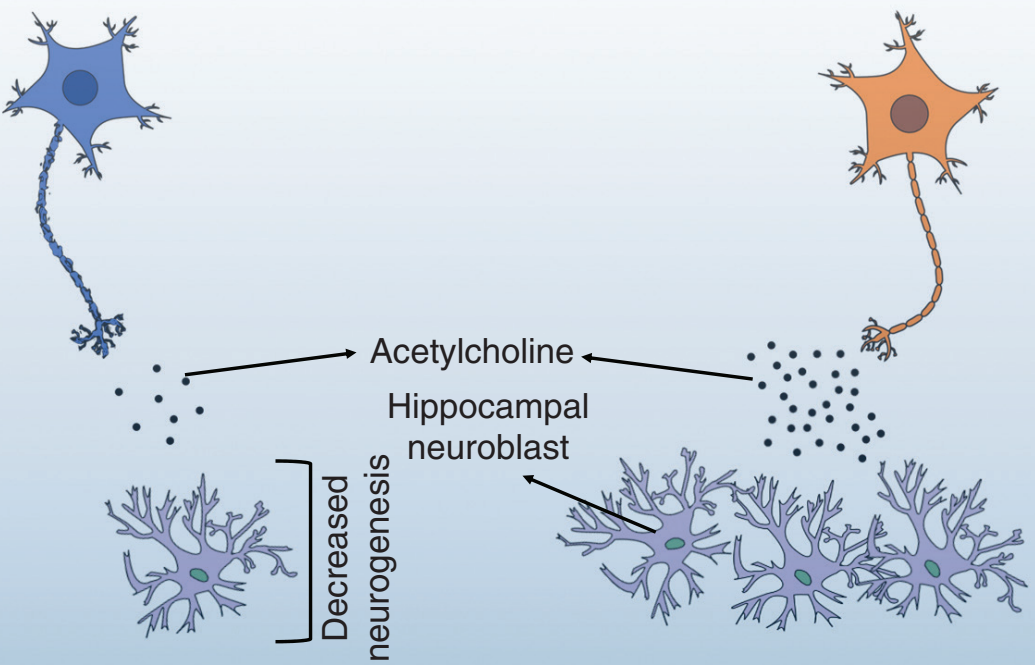

Figure 2 The cholinergic depletion reduced hippocampal neurogenesis that contributes to cognitive impairments. 
receptor (60). The most commonly prescribed anti-depressants, selective serotonin reuptake inhibitors (SSRIs), aim the restoration of serotonin in the central nervous system. The alleviation of depression with SSRIs constitutes the foundation for the serotonin hypothesis of depression in which depressed mood and its complications are accredited to reduced serotonergic neurotransmission and neuromodulation (61). Besides the serotonin transporter (SERT), three sub-types of serotonin receptors, $5-\mathrm{HT}_{1 \mathrm{~A}}, 5-\mathrm{HT}_{1 \mathrm{~B}}$ and $\mathrm{HT}_{2 \mathrm{~A}}$, which are mainly localized in the limbic system, appear to bear higher importance in depression (61). Recently, 5- $\mathrm{HT}_{4}$ and $5-\mathrm{HT}_{6}$ receptors have been suggested to have a role in depression. The stimulation of $5-\mathrm{HT}_{4}$ receptors has been shown to lead to an anti-depressant-like effect that is similar to fluoxetine $(62,63)$. Moreover, $5-\mathrm{HT}_{4}$ stimulation has been found to restore cognitive abilities that are altered in depression (63). An opposite link has been revealed for $5-\mathrm{HT}_{6}$ receptors which are abundant in the hippocampus (64). The inhibition of these receptors has been suggested to exert an anti-depressant-like effect (65). Indeed, the strongest relation between Alzheimer's disease and depression may lie behind the serotonergic system. The patients with Alzheimer's disease display depleted serotonin and 5-hydroxyindoleacetic acid, the main metabolite of serotonin, in their frontal and temporal cortices (49). Amyloidogenic activity increases in the post-menopausal period and this may be originated in decreased serotonergic signaling due to decreased estrogen (66) which is in accordance with the epidemiological data of higher prevalence of Alzheimer's disease in women (67). The Alzheimer's patients have a decreased 5- $\mathrm{HT}_{1 \mathrm{~A}}$ receptor expression particularly in their hippocampi and raphe nuclei, and the hippocampal receptor decrement is correlated with worsened clinical symptoms $(68,69)$. Similarly, $5-\mathrm{HT}_{2}$ receptors decrease up to $69 \%$ in Alzheimer's disease as documented by decreased setoperone binding, a $5-\mathrm{HT}_{2}$ ligand that has particular affinity to $5-\mathrm{HT}_{2 \mathrm{~A}}$ receptors (70), and by decreased altanserin binding, a 5- $\mathrm{HT}_{2 \mathrm{~A}}$ ligand (71). More recently discovered $5-\mathrm{HT}_{4}$ and $5-\mathrm{HT}_{6}$ receptors, which are novel anti-depressant treatment targets, also involve in the pathophysiology of Alzheimer's disease. Similar to that for depression, 5-HT agonism alleviates Alzheimer's amyloidogenic pathology whereas 5- $\mathrm{HT}_{6}$ antagonism augments memory and learning in the Alzheimer's patients (72). Moreover, a decrease in SERT accompanies the decrease in the receptors of interest which results in an extensive disruption in the serotonergic signaling in Alzheimer's disease (73). Overall, the serotonergic system, as summarized in Figure 3, plays a crucial role in both Alzheimer's disease and depression and constitutes a highly promising treatment target which may ease depressive mood while soothing cognitive deficits in the Alzheimer's patients with depression.

In addition to current treatment targets of cholinergic and serotonergic systems in Alzheimer's disease and depression, they share some other pathophysiological features such as disturbances in the hypothalamic-pituitary-adrenal axis, inflammation and oxidative stress (74). However, it is not clear whether these disorders are reasons or consequences. Nonetheless, it is evident that the treatments targeting either cholinergic or serotonergic systems can reduce coinciding immunohumoral and oxidative disruptions to some degree in both diseases $(75,76)$. 


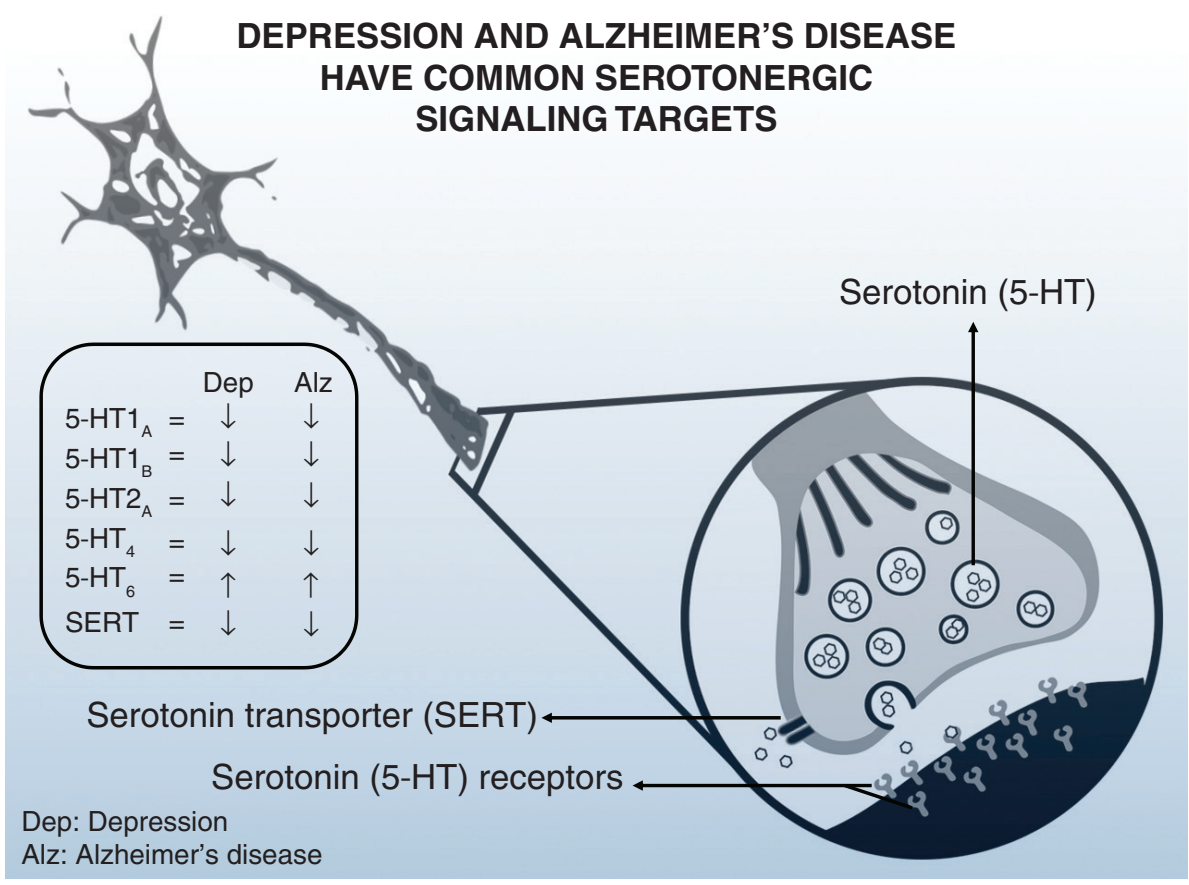

Figure 3 The serotonergic system is similarly altered in both depression and Alzheimer's disease.

\section{CONCLUSION}

Alzheimer's disease and depression are debilitating disorders which need further scrutinization to understand their pathophysiological properties and to develop novel treatment options. Alzheimer's disease is an incurable neurodegenerative disorder, at least for now, and undiagnosed/untreated depression in Alzheimer's patients creates a serious problem since it worsens neurodegeneration while causing further cognitive deficits and lowering quality of life. Considering abovementioned shared molecular features of both disorders, awareness among clinicians of the possibility of depression in Alzheimer's patients would let them prescribe not only against cognitive symptoms, but also affective disturbances which can benefit to both Alzheimer's disease and depression.

Acknowledgments: Images used in the figures have been labeled for "reuse with modification" according to Google Search by Google LLC.

Conflict of interest: The authors declare no potential conflicts of interest with respect to research, authorship, and/or publication of this chapter. 
Copyright and Permission Statement: To the best of our knowledge, the materials included in this chapter do not violate copyright laws. All original sources have been appropriately acknowledged and/or referenced. Where relevant, appropriate permissions have been obtained from the original copyright holder(s).

\section{REFERENCES}

1. Toohey P. Some ancient histories of literary melancholia. Ill Classic Stud. 1990;15(1):143-61.

2. Liu Y, Tang X. Depressive syndromes in autoimmune disorders of the Nervous System: Prevalence, etiology, and influence. Front Psychiatry. 2018 Sep;9:451. http://dx.doi.org/10.3389/fpsyt.2018.00451

3. Alzheimer's Association. 2016 Alzheimer's disease facts and figures. Alzheimers Dement. 2016 Apr;12(4):459-509. http://dx.doi.org/10.1016/j.jalz.2016.03.001

4. Galts CPC, Bettio LEB, Jewett DC, Yang CC, Brocardo PS, Rodrigues ALS, et al. Depression in neurodegenerative diseases: Common mechanisms and current treatment options. Neurosci Biobehav Rev. 2019 Jul;102:56-84. http://dx.doi.org/10.1016/j.neubiorev.2019.04.002

5. American Psychiatric Association. Diagnostic and statistical manual of mental disorders: DSM-5. Washington, DC: American Psychiatric Association Publishing; 2013.

6. Bernaras E, Jaureguizar J, Garaigordobil M. Child and adolescent depression: A review of theories, evaluation instruments, prevention programs, and treatments. Front Psychol. 2019 Mar;10:543. http://dx.doi.org/10.3389/fpsyg.2019.00543

7. Lim GY, Tam WW, Lu Y, Ho CS, Zhang MW, Ho RC. Prevalence of depression in the community from 30 countries between 1994 and 2014. Sci Rep. 2018 Dec;8(1):2861. http://dx.doi.org/10.1038/ s41598-018-21243-x

8. Varinthra P, Liu IY. Molecular basis for the association between depression and circadian rhythm. Tzu-chi Med J. 2019;31(2):67-72. http://dx.doi.org/10.4103/tcmj.tcmj_181_18

9. Demir EA, Oz M, Alp MI, Gergerlioglu HS, Nurullahoglu KE, Yerlikaya FH. Co-administration of cisplatin and curcumin does not alter mood-associated behaviors. Bratisl Lek Listy. 2016;117(2): 106-11. http://dx.doi.org/10.4149/BLL_2016_021

10. Wang J, Wu X, Lai W, Long E, Zhang X, Li W, et al. Prevalence of depression and depressive symptoms among outpatients: A systematic review and meta-analysis. BMJ Open. 2017 Aug;7(8):e017173. http://dx.doi.org/10.1136/bmjopen-2017-017173

11. Lu Y, Mak K-K, van Bever HPS, Ng TP, Mak A, Ho RC-M. Prevalence of anxiety and depressive symptoms in adolescents with asthma: A meta-analysis and meta-regression. Pediatr Allergy Immunol. 2012 Dec;23(8):707-15. http://dx.doi.org/10.1111/pai.12000

12. Caliskan H, Sentunali B, Ozden FM, Cihan KH, Uzunkulakoglu M, Cakan O, et al. Marble burying test analysis in terms of biological and non-biological factors. J Appl Biol Sci. 2017;11(1):54-7.

13. Demir EA, Gergerlioglu HS, Oz M. Antidepressant-like effects of quercetin in diabetic rats are independent of hypothalamic-pituitary-adrenal axis. Acta Neuropsychiatr. 2016 Feb;28(1):23-30. http:// dx.doi.org/10.1017/neu.2015.45

14. Rampello L, Nicoletti G, Raffaele R. Dopaminergic hypothesis for retarded depression: A symptom profile for predicting therapeutical responses. Acta Psychiatr Scand. 1991 Dec;84(6):552-4. http:// dx.doi.org/10.1111/j.1600-0447.1991.tb03193.x

15. Hausmann A, Fleischhacker WW. Differential diagnosis of depressed mood in patients with schizophrenia: A diagnostic algorithm based on a review. Acta Psychiatr Scand. 2002 Aug;106(2):83-96. http://dx.doi.org/10.1034/j.1600-0447.2002.02120.x

16. James SL, Abate D, Abate KH, Abay SM, Abbafati C, Abbasi N, et al. Global, regional, and national incidence, prevalence, and years lived with disability for 354 diseases and injuries for 195 countries and territories, 1990-2017: A systematic analysis for the Global Burden of Disease Study 2017. Lancet. 2018 Nov;392(10159):1789-858.

17. Kessler RC. Epidemiology of women and depression. J Affect Disord. 2003 Mar;74(1):5-13. http:// dx.doi.org/10.1016/S0165-0327(02)00426-3 
18. Mojtabai R, Stuart EA, Hwang I, Eaton WW, Sampson N, Kessler RC. Long-term effects of mental disorders on marital outcomes in the National Comorbidity Survey ten-year follow-up. Soc Psychiatry Psychiatr Epidemiol. 2017 Oct;52(10):1217-26. http://dx.doi.org/10.1016/S0165-0327(02)00426-3

19. Diniz BS, Butters MA, Albert SM, Dew MA, Reynolds CF, 3rd. Late-life depression and risk of vascular dementia and Alzheimer's disease: Systematic review and meta-analysis of community-based cohort studies. Br J Psychiatry. 2013 May;202(5):329-35. http://dx.doi.org/10.1192/bjp.bp.112.118307

20. United Nations, Department of Economic and Social Affairs PD. World population ageing [Internet]. 2017 [cited 2019 Jun 10]. Available from: https:/www.un.org/en/development/desa/population/

21. Qiu C, De Ronchi D, Fratiglioni L. The epidemiology of the dementias: An update. Curr Opin Psychiatry. 2007 Jul;20(4):380-5. http://dx.doi.org/10.1097/YCO.0b013e32816ebc7b

22. Dartigues JF. Alzheimer's disease: A global challenge for the 21st century. Lancet Neurol. 2009 Dec;8(12):1082-3. http://dx.doi.org/10.1016/S1474-4422(09)70298-4

23. Bilgic Y, Demir EA, Bilgic N, Dogan H, Tutuk O, Tumer C. Detrimental effects of chia (Salvia hispanica L.) seeds on learning and memory in aluminum chloride-induced experimental Alzheimer's disease. Acta Neurobiol Exp (Wars). 2018;78(4):322-31. http://dx.doi.org/10.21307/ane-2018-031

24. Crous-Bou M, Minguillón C, Gramunt N, Molinuevo JL. Alzheimer's disease prevention: From risk factors to early intervention. Alzheimers Res Ther. 2017 Dec;9(1):71. http://dx.doi.org/10.1186/ s13195-017-0297-z

25. Wiseman FK, Al-Janabi T, Hardy J, Karmiloff-Smith A, Nizetic D, Tybulewicz VLJ, et al. A genetic cause of Alzheimer disease: Mechanistic insights from Down syndrome. Nat Rev Neurosci. 2015 Sep;16(9):564-74. http://dx.doi.org/10.1038/nrn3983

26. Mitchell AJ, Subramaniam H. Prognosis of depression in old age compared to middle age: A systematic review of comparative studies. Am J Psychiatry. 2005 Sep;162(9):1588-601. http://dx.doi. org/10.1176/appi.ajp.162.9.1588

27. Rovner BW. Depression and increased risk of mortality in the nursing home patient. Am J Med. 1993 May;94(5A):19-22.

28. Reynolds CF, Kupfer DJ. Depression and aging: A look to the future. Psychiatr Serv. 1999 Sep;50(9):1167-72. http://dx.doi.org/10.1176/ps.50.9.1167

29. Olin JT, Katz IR, Meyers BS, Schneider LS, Lebowitz BD. Provisional diagnostic criteria for depression of Alzheimer disease: Rationale and background. Am J Geriatr Psychiatry. 2002;10(2):129-41. http:// dx.doi.org/10.1097/00019442-200203000-00004

30. Lyketsos CG. Neuropsychiatric symptoms (behavioral and psychological symptoms of dementia) and the development of dementia treatments. Int Psychogeriatrics. 2007 Jun;19(3):409-20. http://dx.doi. org/10.1097/00019442-200203000-00004

31. Chi S, Yu J-T, Tan M-S, Tan L. Depression in Alzheimer's disease: Epidemiology, mechanisms, and management. J Alzheimers Dis. 2014 Sep;42(3):739-55. http://dx.doi.org/10.3233/JAD-140324

32. Forsell Y, Jorm AF, Winblad B. Variation in psychiatric and behavioural symptoms at different stages of dementia: Data from physicians' examinations and informants' reports. Dementia. 1993;4(5):282-6. http://dx.doi.org/10.3233/JAD-140324

33. Herz E, Fünfgeld E. Zur Klinik und Pathologie der Alzheimerschen Krankheit. Arch Psychiatr Nervenkr. 1928 Dec;84(1):633-64. http://dx.doi.org/10.1007/BF01814526

34. Pietrzak K, Czarnecka K, Mikiciuk-Olasik E, Szymanski P. New perspectives of Alzheimer disease diagnosis - The most popular and future methods. Med Chem (Los Angeles). 2018 Jan;14(1):34-43.

35. Milwain EJ, Nagy Z. Depressive symptoms increase the likelihood of cognitive impairment in elderly people with subclinical Alzheimer pathology. Dement Geriatr Cogn Disord. 2005;19(1):46-50. http:// dx.doi.org/10.2174/1573406413666171002120847

36. Huppert FA, Brayne C, Gill C, Paykel ES, Beardsall L. CAMCOG - A concise neuropsychological test to assist dementia diagnosis: Socio-demographic determinants in an elderly population sample. Br J Clin Psychol. 1995 Nov;34(Pt 4):529-41. http://dx.doi.org/10.1111/j.2044-8260.1995. tb01487.x

37. Rapp MA, Schnaider-Beeri M, Grossman HT, Sano M, Perl DP, Purohit DP, et al. Increased hippocampal plaques and tangles in patients with Alzheimer disease with a lifetime history of major depression. Arch Gen Psychiatry. 2006 Feb;63(2):161. http://dx.doi.org/10.1001/archpsyc.63.2.161 
38. Brunnström H, Passant U, Englund E, Gustafson L. History of depression prior to Alzheimer's disease and vascular dementia verified post-mortem. Arch Gerontol Geriatr. 2013 Jan;56(1):80-4. http:// dx.doi.org/10.1016/j.archger.2012.10.008

39. Ownby RL, Crocco E, Acevedo A, John V, Loewenstein D. Depression and risk for Alzheimer disease: Systematic review, meta-analysis, and metaregression analysis. Arch Gen Psychiatry. 2006 May;63(5):530-8. http://dx.doi.org/10.1001/archpsyc.63.5.530

40. Green RC, Cupples LA, Kurz A, Auerbach S, Go R, Sadovnick D, et al. Depression as a risk factor for Alzheimer disease. Arch Neurol. 2003 May;60(5):753. http://dx.doi.org/10.1001/archneur.60.5.753

41. Sun X, Chiu CC, Liebson E, Crivello NA, Wang L, Claunch J, et al. Depression and plasma amyloid $\beta$ peptides in the elderly with and without the apolipoprotein E4 allele. Alzheimer Dis Assoc Disord. 2009 Jul;23(3):238-44. http://dx.doi.org/10.1097/WAD.0b013e31819cb3ac

42. Usman S, Chaudhary HR, Asif A, Yahya MI. Severity and risk factors of depression in Alzheimer's disease. J Coll Physicians Surg Pak. 2010 May;20(5):327-30.

43. Zahodne LB, Ornstein K, Cosentino S, Devanand DP, Stern Y. Longitudinal relationships between Alzheimer disease progression and psychosis, depressed mood, and agitation/aggression. Am J Geriatr Psychiatry. 2015 Feb;23(2):130-40. http://dx.doi.org/10.1016/j.jagp.2013.03.014

44. Thiele A. Muscarinic signaling in the brain. Annu Rev Neurosci. 2013 Jul;36(1):271-94. http:// dx.doi.org/10.1146/annurev-neuro-062012-170433

45. Gotti C, Zoli M, Clementi F. Brain nicotinic acetylcholine receptors: Native subtypes and their relevance. Trends Pharmacol Sci. 2006 Sep;27(9):482-91. http://dx.doi.org/10.1016/j.tips.2006.07.004

46. Carruthers SP, Gurvich CT, Rossell SL. The muscarinic system, cognition and schizophrenia. Neurosci Biobehav Rev. 2015 Aug;55:393-402. http://dx.doi.org/10.1016/j.neubiorev.2015.05.011

47. Davies P, Maloney AJ. Selective loss of central cholinergic neurons in Alzheimer's disease. Lancet (London, England). 1976 Dec;2(8000):1403. http://dx.doi.org/10.1016/S0140-6736(76)91936-X

48. Craig LA, Hong NS, McDonald RJ. Revisiting the cholinergic hypothesis in the development of Alzheimer's disease. Neurosci Biobehav Rev. 2011 May;35(6):1397-409. http://dx.doi.org/10.1016/j. neubiorev.2011.03.001

49. Garcia-Alloza M, Gil-Bea FJ, Diez-Ariza M, Chen CPL-H, Francis PT, Lasheras B, et al. Cholinergic-serotonergic imbalance contributes to cognitive and behavioral symptoms in Alzheimer's disease. Neuropsychologia. 2005 Jan;43(3):442-9. http://dx.doi.org/10.1016/j. neuropsychologia.2004.06.007

50. Ferreira-Vieira TH, Guimaraes IM, Silva FR, Ribeiro FM. Alzheimer's disease: Targeting the cholinergic system. Curr Neuropharmacol. 2016 Jan;14(1):101-15. http://dx.doi.org/10.2174/15701 59X13666150716165726

51. Janowsky D, Davis J, El-Yousef MK, Sekerke HJ. A cholinergic-adrenergic hypothesis of mania and depression. Lancet. 1972 Sep;300(7778):632-5. http://dx.doi.org/10.1016/S0140-6736(72)93021-8

52. Dilsaver SC, Coffman JA. Cholinergic hypothesis of depression: A reappraisal. J Clin Psychopharmacol. 1989 Jun;9(3):173-9. http://dx.doi.org/10.1097/00004714-198906000-00003

53. Dagyte G, Den Boer JA, Trentani A. The cholinergic system and depression. Behav Brain Res. 2011 Aug;221(2):574-82. http://dx.doi.org/10.1016/j.bbr.2010.02.023

54. Bassi S, Seney ML, Argibay P, Sibille E. Elevated hippocampal cholinergic neurostimulating peptide precursor protein (HCNP-pp) mRNA in the amygdala in major depression. J Psychiatr Res. 2015 Apr;63:105-16. http://dx.doi.org/10.1016/j.bbr.2010.02.023

55. Aboul-Fotouh S. Behavioral effects of nicotinic antagonist mecamylamine in a rat model of depression: Prefrontal cortex level of BDNF protein and monoaminergic neurotransmitters. Psychopharmacology (Berl). 2015 Mar;232(6):1095-105. http://dx.doi.org/10.1007/s00213-014-3745-5

56. Zhao D, Xu X, Pan L, Zhu W, Fu X, Guo L, et al. Pharmacologic activation of cholinergic alpha7 nicotinic receptors mitigates depressive-like behavior in a mouse model of chronic stress. J Neuroinflammation. 2017 Dec;14(1):234. http://dx.doi.org/10.1007/s00213-014-3745-5

57. Holmes C, Wilkinson D, Dean C, Vethanayagam S, Olivieri S, Langley A, et al. The efficacy of donepezil in the treatment of neuropsychiatric symptoms in Alzheimer disease. Neurology. 2004 Jul;63(2):214-19. http://dx.doi.org/10.1212/01.WNL.0000129990.32253.7B 
58. Tariot PN, Solomon PR, Morris JC, Kershaw P, Lilienfeld S, Ding C. A 5-month, randomized, placebo-controlled trial of galantamine in AD. The Galantamine USA-10 Study Group. Neurology. 2000 Jun;54(12):2269-76. http://dx.doi.org/10.1212/WNL.54.12.2269

59. Reynolds CF, Butters MA, Lopez O, Pollock BG, Dew MA, Mulsant BH, et al. Maintenance treatment of depression in old age. Arch Gen Psychiatry. 2011 Jan;68(1):51. http://dx.doi.org/10.1001/ archgenpsychiatry.2010.184

60. Mohammad-Zadeh LF, Moses L, Gwaltney-Brant SM. Serotonin: A review. J Vet Pharmacol Ther. 2008 Jun;31(3):187-99. http://dx.doi.org/10.1111/j.1365-2885.2008.00944.x

61. Fakhoury M. Revisiting the serotonin hypothesis: Implications for major depressive disorders. Mol Neurobiol. 2016 Jul;53(5):2778-86. http://dx.doi.org/10.1007/s12035-015-9152-z

62. Mendez-David I, David DJ, Darcet F, Wu M V, Kerdine-Römer S, Gardier AM, et al. Rapid anxiolytic effects of a $5-\mathrm{HT}_{4}$ receptor agonist are mediated by a neurogenesis-independent mechanism. Neuropsychopharmacology. 2014 May;39(6):1366-78. http://dx.doi.org/10.1038/npp.2013.332

63. Darcet F, Gardier AM, David DJ, Guilloux J-P. Chronic 5-HT4 receptor agonist treatment restores learning and memory deficits in a neuroendocrine mouse model of anxiety/depression. Neurosci Lett. 2016 Mar;616:197-203. http://dx.doi.org/10.1016/j.neulet.2016.01.055

64. Ly S, Pishdari B, Lok LL, Hajos M, Kocsis B. Activation of 5-HT6 receptors modulates sleep-wake activity and hippocampal theta oscillation. ACS Chem Neurosci. 2013 Jan;4(1):191-9.

65. Wesołowska A. Potential role of the 5-HT6 receptor in depression and anxiety: An overview of preclinical data. Pharmacol Rep. 2010;62(4):564-77. http://dx.doi.org/10.1021/cn300184t

66. Bethea CL, Reddy AP, Christian FL. How studies of the derotonin system in macaque models of menopause relate to Alzheimer's disease. J Alzheimers Dis. 2017 Apr;57(4):1001-15. http://dx.doi. org/10.3233/JAD-160601

67. Beam CR, Kaneshiro C, Jang JY, Reynolds CA, Pedersen NL, Gatz M. Differences between women and men in incidence rates of dementia and Alzheimer's disease. J Alzheimers Dis. 2018 Jul;64(4): 1077-83. http://dx.doi.org/10.3233/JAD-180141

68. Kepe V, Barrio JR, Huang S-C, Ercoli L, Siddarth P, Shoghi-Jadid K, et al. Serotonin 1A receptors in the living brain of Alzheimer's disease patients. Proc Natl Acad Sci. 2006 Jan;103(3):702-7. http://dx.doi. org/10.1073/pnas.0510237103

69. Lanctôt KL, Hussey DF, Herrmann N, Black SE, Rusjan PM, Wilson AA, et al. A positron emission tomography study of 5-hydroxytryptamine-1A receptors in Alzheimer disease. Am J Geriatr Psychiatry. 2007 Oct;15(10):888-98. http://dx.doi.org/10.1097/JGP.0b013e3180488325

70. Blin J, Baron JC, Dubois B, Crouzel C, Fiorelli M, Attar-Lévy D, et al. Loss of brain 5-HT 2 receptors in Alzheimer's disease. Brain. 1993 Jun;116(3):497-510. http://dx.doi.org/10.1093/brain/116.3.497

71. Hasselbalch SG, Madsen K, Svarer C, Pinborg LH, Holm S, Paulson OB, et al. Reduced 5-HT2A receptor binding in patients with mild cognitive impairment. Neurobiol Aging. 2008 Dec;29(12):1830-8. http://dx.doi.org/10.1016/j.neurobiolaging.2007.04.011

72. Geldenhuys WJ, Van der Schyf CJ. Role of serotonin in Alzheimer's disease. CNS Drugs. 2011 Sep;25(9):765-81. http://dx.doi.org/10.2165/11590190-000000000-00000

73. Smith GS, Barrett FS, Joo JH, Nassery N, Savonenko A, Sodums DJ, et al. Molecular imaging of serotonin degeneration in mild cognitive impairment. Neurobiol Dis. 2017 Sep;105:33-41. http://dx.doi. org/10.1016/j.nbd.2017.05.007

74. Wenzlera S, Knöchela C, Balabana C, Krafta D, Kopfa J, Alves G, et al. Integrated biomarkers for depression in Alzheimer's disease: A critical review. Curr Alzheimer Res. 2016 Jun;13(999):1. http:// dx.doi.org/10.2174/1567205013666160603011256

75. McKay MS, Zakzanis KK. The impact of treatment on HPA axis activity in unipolar major depression. J Psychiatr Res. 2010 Feb;44(3):183-92. http://dx.doi.org/10.1016/j.jpsychires.2009.07.012

76. Gałecki P, Mossakowska-Wójcik J, Talarowska M. The anti-inflammatory mechanism of antidepressants - SSRIs, SNRIs. Prog Neuro Psychopharmacol Biol Psychiatry. 2018 Jan;80(Pt C):291-4. http:// dx.doi.org/10.1016/j.pnpbp.2017.03.016 